\title{
Badania radykalizacji kobiet do terroryzmu dżihadystycznego
}

\begin{abstract}
Abstrakt: Celem artykułu jest analiza partycypacji kobiet w ruchach dżihadystycznych z uwzględnieniem perspektyw feministycznych. Hipotezą artykułu jest przypuszczenie, że czynniki warunkujące i inicjujące fascynację przemocą polityczną mogą być inne u kobiet i młodych dziewcząt niż u mężczyzn. Szczególne znaczenie mają uwarunkowania kulturowe i społeczne oraz postrzegane role kobiet w danych społecznościach. Ukazano specyfikę socjalizacji kobiet do przemocy politycznej, nie w kontraście do radykalizacji mężczyzn, ale jako uzupełnienie badań nad terroryzmem. Wykazane zostały przesłanki warunkujące radykalizację postaw i zachowań kobiet, w tym czynniki indywidualne, popychające oraz podtrzymujące zaangażowanie $\mathrm{w}$ terroryzm (push and pull factors). W artykule zostały zastosowane metody badań teoretycznych (klasyfikacja i systematyzacja, weryfikacja), metody ogólnologiczne (analiza, synteza, indukcja, dedukcja) i metody empiryczne (obserwacja pośrednia) oraz inne metody typowe dla nauk społecznych: statystyczna, komparatywna, opisowa, analizy i krytyki źródeł oraz piśmiennictwa. W konkluzji stwierdzono, że manipulacja męskością i kobiecością wykorzystywana jest nie tylko przez ugrupowania terrorystyczne w procesach rekrutacyjnych, ale także w analizach samego zjawiska. Relacyjność płci wpływa na przyjęte rozwiązania interpretacyjne w naukach społecznych, przede wszystkim na marginalizację kobiet w badaniach nad przemocą.
\end{abstract}

Słowa kluczowe: feminizm, kobiety, terroryzm dżihadystyczny, terroryzm z udziałem kobiet, radykalizacja

$\mathbf{N}$ ierówna pod względem płci liczba sprawców przestępstw o charakterze terrorystycznym jest faktem, z którym trudno dyskutować. Niemniej płciowa luka w przestępczości (gender gap in crime), która znajduje odzwierciedlenie w statystykach nie oznacza, że kobiety nie odgrywają tych samych ról co mężczyźni w organizacjach terrorystycznych. Ich funkcje w popełnianiu przestępstw przeciwko życiu i zdrowiu oraz czynów zabronionych związanych z niszczeniem mienia, nawoływaniem do popełnienia przestępstwa, pozyskiwaniem funduszy na działalność przestępczą są równie ważne, jak męskich członków ugrupowań terrorystycznych. W dalszym ciągu jednak utrwalony przez kulturę podział na to, co męskie i żeńskie sprawia, że terroryzm z udziałem kobiet postrzegany jest jako obcy, nienaturalny, będący na skraju dewiacji. Opiekunka i strażniczka domowego ogniska nie może być przecież zdolna do odbierania życia, a jednak jest. Mimo iż przestępczość polityczna kobiet wzrasta i zamiast być traktowana jako wyzwanie dla systemów przeciwdziałania, marginalizuje się jej zauważalny wzrost oraz potencjalne konsekwencje.

Partycypacja kobiet jest widoczna również w terroryzmie zaliczanym do kategorii islamskiego. Dywersyfikacja ról i funkcji ulega poszerzaniu o wcześniej dostępne zadania tylko dla mężczyzn (przeszkolenie militarne, akcje zbrojne, wyznaczanie kierunków polityki ugrupowania). Udział kobiet w charakterze zamachowczyń odnotowywany jest m.in.: w Al-Qa'idzie i jej filiach regionalnych, tzw. Państwie Islamskim (ISIS/Da'isz), Boko Haram oraz Palestyńskim Islamskim Dżihadzie. Członkinie niektórych z tych or- 
ganizacji aktywne są na terenie Europy Zachodniej (Groen, Kranenberg, 2010). Do politycznej awangardy, związanej z wytyczaniem ogólnych kierunków rozwoju organizacji oraz jej zaplecza ideologicznego, kobiety dopuszczane są rzadko. W 2005 roku wybrano do Rady Politycznej Hezbollahu pierwszą kobietę Rimę Fakhri, później Afaf al-Hakim, przewodnicząca grupy kobiet, uzyskała prawo udziału w pracach Komitetu Wykonawczego. Kobiety początkowo pełniły funkcję pomocniczą w działalności tej organizacji, ich role i zadania ewaluują (Zięba, 2015, s. 57).

Podstawę analizy problemu radykalizacji kobiet do terroryzmu dżihadystycznego stanowią teorie feministyczne w zakresie studiów nad bezpieczeństwem. Feminizm, podobnie jak podejście human security, proponuje analizę bezpieczeństwa z dołu do góry, czyli od jednostki poprzez społeczność lokalną do sytuacji międzynarodowej. Podejście to jest dwutorowe, gdyż wiąże bezpieczeństwo jednostki z bezpieczeństwem narodowym i międzynarodowym, przy jednoczesnym wpływie tych ostatnich na jednostki (Tickner, 1997, s. 187). Jeżeli role i doświadczenie kobiet będą pomijane w tych rozważaniach, interpretacja wszelkich zjawisk społecznych pozostaje niepełna. Należy przy tym zaznaczyć, że nie ma feministycznej teorii wojny tak, jak i feministycznej teorii terroryzmu. Feminizm nie rości sobie prawa do jej stworzenia, tylko zwraca uwagę na wyłączenie kobiet, które stanowią połowę populacji na Ziemi. Historia wojen pozostaje domeną mężczyzn, ich triumfów i upadków. Fakt, że to głównie mężczyźni odgrywali role aktywne w przemocy politycznej wpływa na interpretację zjawisk z zakresu pojmowania konfliktów zbrojnych i walki zbrojnej w ogóle. Kobiety były i są utożsamiane z byciem ofiarą wielkiej historii, która wydarza się poza nimi, a której konsekwencje najdotkliwiej ponoszą. Mit wyższości mężczyzn, utrwalający ich pozycję poprzez system zarządzania przemocą, wydzielił osobne role dla mężczyzn i kobiet: rolę męską związaną z panowaniem i przemocą oraz żeńską podporządkowaną i słabą. Płeć w tym ujęciu stała się zjawiskiem politycznym, gdyż odnosi się do relacji władzy między „nim a nią”, która przekłada się na całokształt relacji międzyludzkich w obrębie systemu społecznego (Millett, 2005, s. 42). Kobieta uwięziona w sieci oczekiwań, standardów i instrukcji trwale wpisała się w przestrzeń prywatną, będąc jedynie upokarzanym refleksem męskich działań zapewniających jej ochronę lub kontrolę. Szczególnie pozycja kobiety deprecjonowana jest przez patriarchalne systemy. Bliski Wschód postrzegany jest jako „bijące serce mizoginii” ukonstytuowane przez kulturę i religię, gdzie ciało oraz umysł kobiety należy do opiekuna-mężczyzny, męża, ojca, brata (Eltahawy, 2016, s. 12). Motywacje emancypacyjne nie odzwierciedlają rzeczywistych pobudek fascynacji terroryzmem kobiet i młodych dziewcząt.

\section{Specyfika radykalizacji kobiet i dziewcząt}

Problem radykalizacji kobiet do terroryzmu i brutalnego ekstremizmu staje się współcześnie jednym z największych wyzwań dla systemów przeciwdziałania terroryzmowi (Cook, 2019). Terroryzm to nie jest sam akt terrorystyczny, ale całokształt nielegalnych działań podejmowanych przez organizacje terrorystyczne, ich otoczenie sympatyzujące i wspierające. Szczególnie w tych ostatnich przestrzeniach rola kobiet jest coraz bardziej widoczna, jako rekruterek, agitatorek, zapewniających zaplecze logistyczne, szpiegów, strategów, spiskowców, a nawet zamachowczyń. Zjawisko dywersyfikacji kobiecej aktyw- 
ności terrorystycznej poszerza się niezależnie od nurtów terrorystycznych i szerokości geograficznej. Zauważalny wzrost takiej formy przestępczości kobiet nastąpił w latach 60. i 70. XX wieku. Pojawił się nowy typ ,terrorystki”, która pełni te same role i wykonuje takie same zadania, co mężczyzna. Dzięki takim świeckim ugrupowaniom jak Akcji Bezpośredniej, Czarnym Panterom, Czerwonym Brygadom, Frakcji Czerwonej Armii, Irlandzkiej Armii Republikańskiej oraz ETA zmiana w postrzeganiu czynów zabronionych przez kobiety była skokiem ilościowym i jakościowym. Ta ewolucja pozostała niedostatecznie zauważona w badaniach nad terroryzmem oraz przez instytucje odpowiedzialne za przeciwdziałanie tym formom przemocy. Kobiety pozostały mniej widoczne w porównaniu do mężczyzn zaangażowanych $\mathrm{w}$ terroryzm, mimo że stały się pełnoprawnymi terrorystycznymi aktorami (Gasztold, 2019). Przekonanie o ich pasywności umiejętnie wykorzystywane jest przez organizacje terrorystyczne, szczególnie te, które dotychczas postrzegane były jako wrogie członkostwu kobiet (np. organizacje prawicowe: świeckie i religijne).

Zaangażowanie kobiet na rzecz organizacji terrorystycznej wpływa także na „ocieplenie" wizerunku grupy. Proceder ten na przykład w ostatnich latach był wykorzystywany w Internecie przez Da'isz (Państwo Islamskie) w celu pozyskania nowych rekrutek, szczególnie wśród młodych dziewcząt. Umieszczenie zdjęć kobiet w szeregach terrorystów adresowane było do potencjalnych zwolenniczek. Sprzyja to wyobrażeniu wyboru normalnego stylu życia i może być jednym z czynników legitymizujących istnienie oraz cele Państwa Islamskiego (Klausen, 2014). Skuteczność strategii ,jihadi bride" (zaślubiona dżihadowi) pokazują dane szacunkowe haskiego Międzynarodowego Centrum Przeciwdziałania Terroryzmowi (International Center for Counter-Terrorism, ICCT). Wykazano, że na terenie Syrii i Iraku w charakterze zagranicznych bojowników z UE przebywało do wiosny 2016 roku 3922-4294 osób, z czego prawdopodobnie 17\% stanowiły kobiety (ok. 666-730 osób). Przypuszczalnie przeważająca część z nich pochodziła z obszarów miejskich Belgii, Niemiec oraz Wielkiej Brytanii (ICCT, 2016, s.4-5). W ostatnich latach drastyczny wzrost zaangażowania kobiet na rzecz dżihadyzmu (szacowana średnia wieku 27 lat) odnotowano również w Stanach Zjednoczonych (Alexander, 2016). Prawdopodobnie większość została zachęcona powołaniem z początkiem lutego 2014 roku żeńskiej brygady Al-Chansaa, zwanej potocznie Jihadi Girl Power. Fakt wprowadzenia przez Da'isz systemu niewolnictwa seksualnego wydaje się nie być wystarczająco odstraszającym czynnikiem, mimo publikowanych relacji kobiet, którym udało się zbiec z obozów terrorystów (Jinan, 2015; Khalaf, Hoffman 2016).

Kobiety utrzymywały i propagowały ideologię Państwa Islamskiego. Kluczową ich rolą była rola żony i matki. Wspierały swoich mężów zaangażowanych w działania tej organizacji. Poprzez wychowanie dzieci zgodnie z narzuconymi dżihadystycznymi regułami zapewniały przetrwanie tej organizacji. Rekrutowały też inne osoby, brały aktywny udział w tzw. kojarzonych małżeństwach, ale także pełniły role kurierskie przy przewożeniu nie tylko informacji, ale także broni i materiałów wybuchowych. Na mniejszą skalę dopuszczane były do funkcji bojowników, planowały i przeprowadzały ataki, w tym samobójcze. Jako drogi radykalizacji wymienia się m.in. (Leede de i in., 2017, s. 23-24):

- potrzebę przynależności i określenia tożsamości, co ma szczególne znaczenie wśród dzieci imigrantów;

- tęsknotę za czystością, byciem szanowaną (w tym mieści się krytyka i odrzucenie idei zachodniego feminizmu) podtrzymywaną przez idealistyczną wizję Kalifatu; 
- potrzebę udziału w kosmicznej wojnie, gdzie binarny podział świata urasta do totalnej walki dobra ze złem;

- identyfikowanie się ze społecznością islamską (Umma);

- doświadczenie przygody;

- perspektywa małżeństwa;

- chęć udziału w realizacji boskiego planu, odrzucenie materializmu i zachodniej powierzchowności (w tym mieści się alternatywa dla zachodniego feminizmu) na rzecz czegoś większego i głębszego.

Radykalizację w kierunku terroryzmu kobiet można badać, biorąc pod uwagę: podatność, sposób rekrutacji i metody indoktrynacji oraz działania, przy jednoczesnym uwzględnieniu uwarunkowań psychologicznych, społecznych, ekonomicznych oraz politycznych. Tożsamość jednostki osadzonej w określonym kontekście społeczno-kulturowym może mieć kluczowe znaczenie w określeniu przesłanek, które mogą popchnąć osobę w kierunku przemocy. Jest to o tyle istotne, że czynniki mogące składać się na uwarunkowania, należy rozpatrywać przez pryzmat ujęcia systemowego na różnych płaszczyznach, które są wzajemnie powiązane (Wejkszner, 2018, s. 48-64). Alex P. Schmid proponuje badanie problemu radykalizacji na trzech poziomach: mikro, mezo i makro. Pierwszy poziom dotyczy kwestii tożsamości jednostki oraz roli czynników stwarzających poczucie frustracji, które mogą prowadzić do agresji (rozładowanie gniewu) lub potrzeby czynu/zmiany, zemsty lub działań odwetowych. Drugi poziom dotyczy środowiska, trzeci zaś ogólnie systemu (Schmid, 2013).

Mia Bloom wyróżniła kilka motywów, którymi kierują się zamachowczynie-samobójczynie. Są to tzw. 4R plus 1, czyli: zemsta (revange), odkupienie (redemption), szacunek (respect), związek (relationship), dodatkowo gwałt (rape) jako zdarzenie traumatyzujące, mogące być katalizatorem działań terrorystycznych (Bloom, 2011, s. 234-236). Wymienione 4R równie dobrze charakteryzują motywację mężczyzn. Choć kobiety mogą być wystawione na radykalizację w inny sposób. Dotyczy to przede wszystkim tradycyjnych wzorców zachowań i kultury patriarchalnej. Dobrym przykładem jest mechanizm wpędzania w poczucie winy nazywany „pułapką czystości”. Podatność na radykalizację może mieć związek z seksualnością i normami oraz wzorcami zachowań w obrębie danej kultury/religii. Czystość seksualna jako motywacja może wynikać z przemocy seksualnej. Ciało kobiety i jej cnota w wielu kulturach patriarchalnych symbolicznie powiązane jest z honorem rodziny, klanu, narodu. Stąd opinia publiczna, w której silne są podziały ról między płciami, może akceptować zamachy samobójcze kobiet, szczególnie gdy idea walki nawiązuje do oporu wobec okupanta czy haseł narodowowyzwoleńczych (np. w Czeczenii czarne wdowy, w Autonomii Palestyńskiej Hamas lub Palestyński Islamski Dżihad, w Iraku ataki z ramienia Al-Qa'idy). Kobieta jako ofiara przemocy seksualnej jest zhańbiona i już na zawsze naznaczona. Jej zaangażowanie na rzecz grupy terrorystycznej nadaje jej życiu nowy sens oraz jest źródłem siły fizycznej i psychicznej. Uwalnia ją od ostracyzmu, wykluczenia i negatywnej oceny oraz czyni częścią większej sprawy/społeczności. W pewien sposób staje się równa męskim bojownikom - zwłaszcza w ruchach świeckich o charakterze narodowowyzwoleńczym, jak np. Tamilskie Tygrysy Wyzwolenia Illamu, Partia Pracujących Kurdystanu (Herath, 2012; Alison, 2009), ale nie w grupach o silnej tożsamości religijnej (Hamas, Al-Qa'ida, Da’isz). Świadczyć może o tym teologiczna obietnica mniejszej nagrody pośmiertnej 
dla męczennicy związana z wybaczeniem grzechów, czy posiadaniem jednego męża. Szczególnie problematyczne jest zapewnienie uciech w niebiańskim ogrodzie na równi z mężczyznami (Quazi, 2011, s. 35). Należałoby się zastanowić czy wobec tego decyzja kobiety nie jest wynikiem postrzegania płciowego i presji oczekiwań, które dyskryminuje samostanowienie kobiet.

Pytania dotyczące kobiecej tożsamości, zmysłowości i fizyczności mogą być przemilczane lub niewygodne na łonie rodziny. Stąd na przykład ISIS/Da’isz, rekrutując młode kobiety i dziewczyny w Europie, umożliwiał im kontakty seksualne np. poprzez nieformalne małżeństwa, wypełniając sferę zabronioną swoistym przyzwoleniem. Po utracie dziewictwa młode kobiety znajdowały się w schizofrenicznej sytuacji, z jednej strony obawiały się, że mogą być odrzucone przez swoje rodziny, z drugiej zaś jeszcze bardziej izolowały się i radykalizowały (Leede de i in., 2017, s. 62). Mechanizm podobny może wystąpić również w sytuacji przymuszonego kontaktu seksualnego - gwałtu.

Ważne jest również środowisko, w którym funkcjonuje jednostka. Osoby najbliższe, w tym rodzina, koledzy, koleżanki, sąsiedzi oraz sieci społeczne mogą obudzić fascynację działalnością polityczną organizacji/ruchu/sprawy, ale także będą indoktrynowały (wzorce osobowe, społeczne korzyści, rola autorytetu) i monitorowały proces stawania się oraz bycia terrorystą. Według teorii tożsamości społecznej Henriego Tajfela i Johna Turnera grupa staje się punktem odniesienia, który scala się w oparciu o kontrast pomiędzy sprzymierzeńcami (w obrębie grupy) i wrogim otoczeniem tworzonym przez przedstawicieli pozostałych struktur oraz związków międzyludzkich (poza grupą). Tłumaczy to faworyzowanie swojej grupy a poniżanie innych (Tajfel, Turner, 1979, s. 33-47). Poczucie lojalności i solidarności oraz konformizm grupowy i posłuszeństwo mogą wpływać na postępującą radykalizację w kierunku terroryzmu. Z analizy Edwina Bakkera (badania dotyczyły Europy: 242 dżihadystów, w tym 5 kobiet) wynika, że od roku 2001 jednostki zazwyczaj angażują się w terroryzm poprzez przyjaciół lub krewnych i że nie mają formalnych związków z globalnymi sieciami salafickimi, a proces radykalizacji zachodzi niezależnie od wysiłków konkretnego rekrutera Al-Qa’idy (Bakker, 2006).

W przypadku analizy uwarunkowań systemowych (poziom makro) należy uwzględnić trendy postaw i zachowań opinii publicznej. Ten model uwzględnia politykę zewnętrzną i wewnętrzną państwa, w którym jednostka żyje. Czynniki mogące być katalizatorami fascynacji przemocą i jej użyciem nie zawsze tworzą kompleksową odpowiedź na pytanie: kto zostanie terrorystą/ką. Zdarzenia przyspieszające frustrację dotykają całej populacji, a tylko nieliczne jednostki dokonują aktów terroru. Ta forma analizy może być wykorzystywana do badania radykalizacji prowadzącej do zaangażowania w grupach terrorystycznych, lecz już nie w działaniach tzw. samotnych wilków. Przeważnie samotnikami są mężczyźni, dotyczy to też ataków zaliczanych do terroryzmu dżiahdystycznego, jak np. strzelanina zainicjowana 5 listopada 2009 r. w Fort Hood przez Nidala Malika Hasana czy samobójczy atak w centrum Sztokholmu Taimura Abdulwahaba z 11 grudnia 2010 r. Kobietą, która spełnia kryteria samotnej radykalizacji, jest Roshonara Choudhry, Brytyjka o bengalskich korzeniach. Choudhry zradykalizowała się poprzez Internet i 14 maja 2010 roku ugodziła nożem członka Partii Pracy Stephena Timmsa. Za próbę zabójstwa oraz powiązania z Al-Qai' dą została skazana na dożywocie, jako pierwsza kobieta-dżihadystka w Wielkiej Brytanii (Pearson, 2016). Profil samotnego wilka jednak jest rzadko spotykany u kobiet. 
Ogromną rolę odgrywają w procesie rekrutacji na rzecz terroryzmu osoby kształtujące więzi emocjonalne. W dalszym ciągu rekrutacja „na miłość” (więź uczuciową) jest praktykowana.

Czynniki przyczynowe nie muszą mieć same w sobie radykalizującej mocy sprawczej. Są też łatwiejsze do zdiagnozowania i przewidzenia niż ma to miejsce w przypadku incydentów czy bodźców określanych jako katalizatory. Te z kolei, nie są zdolne samodzielnie zainicjować samego procesu radykalizowania się. Jest to możliwe dopiero w wyniku określonej kombinacji katalizatora $\mathrm{z}$ czynnikami pochodzącymi z wymiaru makro, mezo czy indywidualnego. Za jeden z kluczowych czynników przyspieszających można np. uznać opublikowanie karykatur Mahometa w Danii i ich przedruk w wielu innych państwach UE, co zainicjowało falę procesu radykalizacji niektórych osób i grup w Europie oraz w Stanach Zjednoczonych. Pierwszą gazetą, która je rozpowszechniła w 2006 roku, była duńska „Jyllands-Posten”. Lokalna szwedzka gazeta „Nerikes Allehanda" 19 sierpnia 2007 opublikowała rysunek przedstawiający głowę proroka Mahometa na ciele psa, również inne gazety europejskie poszły jej śladem. Wywołało to szereg protestów w krajach muzułmańskich. Abu Omar al-Baghdadi, przedstawiciel terrorystycznej organizacji Al-Qa'ida w Iraku, wyznaczył 100 tys. dolarów nagrody za zabójstwo rysownika Larsa Vilksa. Na 50 tys. USD nagrody wyceniono życie Ulfa Johanssona - redaktora naczelnego „Nerikes Allehanda”. W tym kontekście przykładem dość szczególnym jest sprawa Amerykanki Coleen R. LaRose, okrzykniętej przez media Jihad Jane. Sławę zyskała m.in. poprzez swoją aktywność (jako Fatima La Rosa) w propagowaniu idei dżihadu w sieci Internet (YouTube, MySpace) oraz zaangażowanie w sprawę słynnych karykatur. Została aresztowana w 2009 roku i na początku 2014 roku skazana na 10 lat więzienia za udział w nielegalnym spisku, którego celem było zabójstwo znanego szwedzkiego rysownika Larsa Vilksa. Znamienne jest to, że LaRose przeprosiła za swoje zachowanie i zadeklarowała, że nie będzie brała więcej udziału w ,świętej wojnie”. Zwolennicy teorii decydującego czynnika osobowościowego w radykalizacji uważają, że kwestie wiary mogą być drugorzędnym bodźcem. Zgodnie z tym założeniem, droga do dżihadyzmu LaRose, mogła nie mieć bezpośredniego związku z jej wiarą, o czym świadczy jej skrucha po zatrzymaniu. Radykalna interpretacja islamu przypuszczalnie stanowiła czynnik dodatkowy radykalizacji, ale nie jej źródło, w okresie poprzedzającym dokonanie zamachu-doświadczyła serii traumatycznych przeżyć. Jako dziecko była wykorzystywana seksualnie przez swojego biologicznego ojca, po ucieczce $\mathrm{z}$ domu w wieku 13 lat utrzymywała się z prostytucji, poroniła, potem nie mogła mieć dzieci, jej dwa małżeństwa się rozpadły. W 2005 r. będąc na skraju wyczerpania psychicznego, po śmierci ojca i brata, podjęła próbę samobójczą. Traumatyczna biografia i stan emocjonalny, w jakim się znajdowała, zostały umiejętnie wykorzystane przez przypadkowo poznanego w barze rekrutera, następnie była ,prowadzona” przez islamistów o pseudonimie Eagle Eye i Black Flag/Ali Charaf Damache (Schiffman, 2012).

\section{Model push and pull factors}

Radykalizacja do terroryzmu według niemieckiego badacza Rolanda Eckerta kieruje się pewną logiką, w której można wyróżnić siedem kroków: 1) kulturową definicję kolek- 
tywu; 2) postrzeganą deprywację; 3) unikatową ofertę kolektywnej tożsamości i rekrutację; 4) wpływ gwałtownych wydarzeń; 5) nadanie znaczenia poprzez filozofię dziejową; 6) wiktymizację poprzez przeciwstawienie oraz solidarność z kolektywem; 7) konsolidację strachu i nienawiści, która może przechodzić na dalsze pokolenia (np. w przypadku nierozwiązanych kwestii narodowowyzwoleńczych) (Eckert, 2009, s. 5-6). Ogromne znaczenie ma pierwszy krok i punkt odniesienia do większej społeczności, etnicznej, religijnej czy kulturowej. Warto zaznaczyć, że dana osoba nie zawsze utożsamia się z grupą, z której się wywodzi. Identyfikacja może odnosić się do wielkich i abstrakcyjnych wyimaginowanych wspólnot, takich jak: naród, klasa, rasa, wyznanie. W przypadku zaostrzania się konfliktu te kolektywy stają się podmiotem historii z wyraźnym kontrastem i rozgraniczeniem na swoi-obcy/my-oni oraz spoiwem solidarności. Dodatkowo idea np. „wyzwolonego narodu”, „bezklasowego społeczeństwa” czy „wspólnoty muzułmańskiej” jest nie tylko punktem odniesienia jednostki, ale i projektem przyszłości (Anderson, 2006). Na przykład II i III pokolenie muzułmanów w krajach cywilizacji zachodniej nie czuje związku emocjonalno-kulturowego ze swoimi rodzicami oraz społeczeństwem kraju zamieszkania, poszukuje wzorców w idei wspólnoty wiernych (Umma). Hybrydowa tożsamość (np. Brytyjczyk-Pakistańczyk, Niemiec-Irakijczyk) charakterystyczna dla dzieci emigrantów nie jest akceptowana przez żadną z dwóch grup, w której jednostka funkcjonuje i przyspiesza proces definiowania się $w$ kategoriach religijnych. Pomocne mogą być $\mathrm{w}$ tym inne niż rodzina sieci społeczne, szczególnie wpływ znajomych, ale także namnażające się portale społecznościowe o określonej tematyce (Zięba, Szlachter, 2015).

Kobiety o wiele częściej radykalizują się w grupie, szczególnie wtedy, gdy oferuje im ona przywództwo, przyjaźń, bezpieczeństwo i cel. Czyli wszystko to, co powinna zapewnić rodzina. Innymi czynnikami, o których warto wspomnieć, jest silna indoktrynacja granicząca często z manipulacją emocjonalną i zastraszaniem oraz wzorowanie się na poprzednikach, czyli mity i legendy kryjące się pod propagandowymi działaniami organizacji terrorystycznej. Wizerunek kobiety terrorystki i mężczyzny (tudzież osoby zaangażowanej w walkę o sprawę, z punktu widzenia organizacji) może odwoływać się do zupełnie różnych etosów i symboliki w zależności od kręgu kulturowego, celów organizacji oraz społeczności referencyjnej.

W kształtowaniu strategii przeciwdziałania radykalizacji postaw i zachowań prowadzących do terroryzmu często jest wykorzystywany model czynników popychających i przyciągających push and pull factors (Lützinger, 2010; Bjørgo, 2005). W poniższej tabeli przedstawiono wybrane bodźce, które mogą mieć wpływ na proces radykalizacji w przypadku kobiet i młodych dziewcząt. Poniższy rejestr jest katalogiem otwartym.

Tabela 1

Radykalizacja kobiet do terroryzmu. Czynniki popychające i przyciągające

\begin{tabular}{|c|c|}
\hline Push-factors & Pull-factors \\
\hline 1 & 2 \\
\hline $\begin{array}{ll}- & \text { poczucie odizolowania społecznego i/lub kul- } \\
& \text { turowego, } \\
- & \text { poszukiwanie własnej tożsamości i przynależ- } \\
& \text { ności, } \\
- & \text { doświadczenie dyskryminacji i/lub społecznej } \\
& \text { niesprawiedliwości, }\end{array}$ & $\begin{array}{l}\text { - } \text { poczucie przynależności, identyfikacja z grupą, } \\
\text { - } \text { więź emocjonalna, } \\
\text { - } \text { rola rodziny, w tym zaangażowanie innych człon- } \\
\text { ków rodziny, } \\
\text { - } \text { pobyt w więzieniu, } \\
\text { - } \\
\text { presja grupy i dynamika grupowa, }\end{array}$ \\
\hline
\end{tabular}




\begin{tabular}{|c|c|}
\hline 1 & 2 \\
\hline 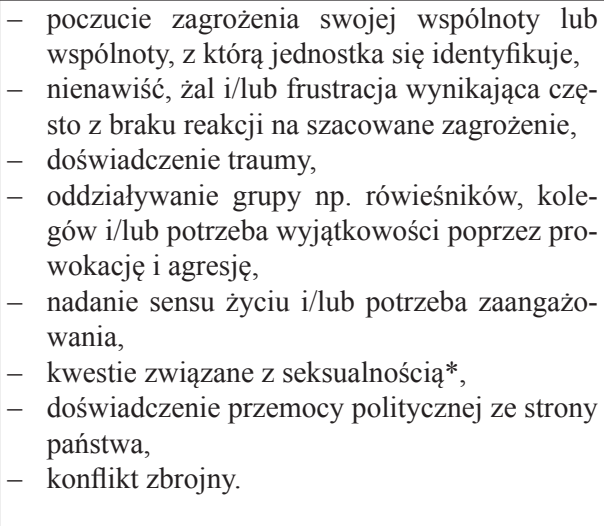 & 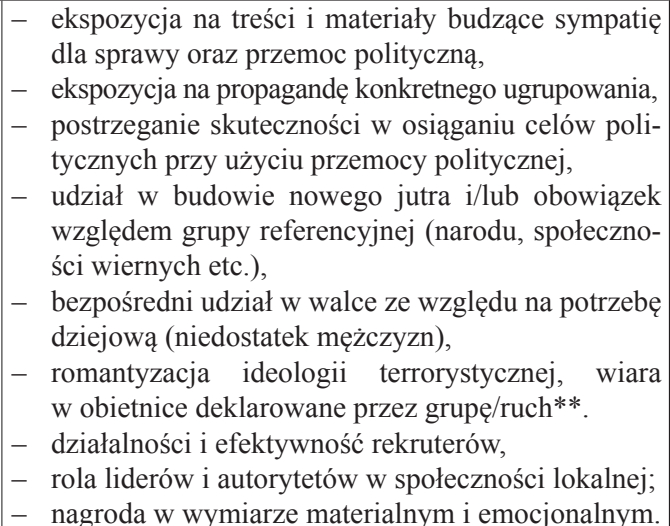 \\
\hline
\end{tabular}

* Mogą mieć szczególnie znaczenie w konserwatywnym wychowaniu młodych dziewcząt. Nacisk na czystość seksualną zderza się z liberalnym podejściem np. w demokracjach zachodnich.

** Na przykład w hasła równego statusu z mężczyznami, wyzwolenia, małżeństwa, edukacji, życia po śmierci itd.

Źródło: Zestawienie własne.

Czynnikami, które niewątpliwie wzmacniają proces radykalizacji, są czynniki osobiste, które określają psychologiczną podatność niezależnie od innych uwarunkowań. Zaliczyć można do nich m.in. zdrowie psychiczne, w tym stan żałoby, depresję; cechy osobowości, jak impulsywność, kompulsywność, narcyzm; indywidualne określone wskaźniki, np. wiek, płeć, poziom wykształcenia, przynależność państwową, narodową, stan cywilny, aktywność zawodową (Vergani, 2018). Inni badacze problemu zaangażowania kobiet w terroryzm również akcentują czynniki osobiste, bezpłodność lub też pozostawanie niezamężną, co stygmatyzuje daną kobietę w patriarchalnych społeczeństwach (Victor 2003, Bloom, 2011). Jednak pobudki indywidualne (cele/motywy subiektywne jednostki) mogą być nieracjonalne, niespójne, pozbawione sensu (działania kompulsywne, niedojrzałość emocjonalna, zaburzenia tożsamości, wewnętrznie sprzeczna struktura osobowości itd.). Należy zatem uwzględniać racjonalność samego celu do jakiego zmierza organizacja czy ruch terrorystyczny, z którym identyfikuje się jednostka.

\section{Kobieta, terrorystka, zamachowczyni}

Szczególnie w przypadku zamachów terrorystycznych dokonywanych przez kobiety obserwowana jest pewna płciowa schizofrenia wynikająca z użytecznej, umiejscowionej w kontekście historycznym potrzeby akceptacji konkretnego zachowania. Wyobrażenie kobiety-męczennicy obejmuje kulturowo przyjęte i akceptowane normy kobiecości, a jednocześnie wychodzi poza te normy. Utrwalany jest obraz zamachowczyni, jako skromnej, dobrej istoty, która oczyszcza honor rodziny poprzez swoje osobiste zaangażowanie, przy jednoczesnym wizerunku zaciekłej, odważnej na równi z mężczyzną, walczącej w imię sprawy (Ness, 2005, s. 362). Wszelkie debaty w tym zakresie mieszczą się w rozważaniach o gender. Wybór kobiety nie jest równy z wyborem mężczyzny. Jest 
„tak obcy i nienaturalny dla kobiet, że musi istnieć wyjaśnienie poza tym, że kobiety chcą walczyć ze swoich określonych powodów" (Cunningham, 2003, s. 186). Obsesyjna potrzeba kontroli nad ciałami i umysłami kobiet charakterystyczna dla systemów patriarchalnych wkracza nawet $\mathrm{w}$ decydowanie o samobójstwie. Typowo męskie objaśnienia doświadczeń i przeżyć kobiet wpisują się w potoczne rozumienie terminu mansplaining (man/mężczyzna + explaining/wyjaśnianie).

Zatem ataki samobójcze kobiet interpretowane są poprzez ekspozycję ciała, seksualności lub emocjonalności (bezdzietność, niezamężność, kalectwo, utrata najbliższych, gwałt). Prawdopodobnie pierwszą kobietą, która dokonała samobójczego ataku, była 16-letnia Sana'a Mehaidli, chrześcijanka z południowego Libanu. Zdarzenie to miało miejsce 9 kwietnia 1985 roku. Mehaidli była członkinią Syryjskiej Partii Socjal-Nacjonalistycznej (SSNP). Również narodowowyzwoleńcze Tamilskie Tygrysy Wyzwolenia Illamu od początku swego istnienia (1976 r.) tworzyły komanda kobiecie („Ptaki Wolności”) i samobójcze („Czarne Tygrysy”), w których przeważnie kobiety przeprowadzały ataki. Jedna z członkiń Tygrysów zamordowała w 1991 roku premiera Indii Rajiva Gandhiego, inna w 1993 roku prezydenta Sri Lanki - Ranasinghe Premadasę. Organizacje islamskie później niż ruchy świeckie zaczęły wykorzystywać kobiety jako żywe bomby. Największy wzrost udziału kobiet w zamachach samobójczych przypada na apogeum konfliktu w Iraku i rok 2008 (35 zamachów), następnie w roku 2015 (52 ataki) pod auspicjami Boko Haram w Nigerii i Czadzie. Główną metodą stosowaną w przeprowadzeniu zamachu samobójczego przez kobiety było użycie pasów z materiałem wybuchowym (83,3\%). Dane odnośnie poziomu wykształcenia, wyznania, statusu zawodowego są niepełne i nie pozwalają na skonstruowanie wiarygodnego i powtarzalnego wzorca kobiety-terrorystki (CPOST-SAD, 2018). Znamienny przykład stanowią samobójcze ataki bombowe przeprowadzone z końcem lipca 2014 roku w Kano (Nigeria). Jedna z niedoszłych zamachowczyń miała 10 lat (sic!). Sukcesy zamachów dokonanych przez kobiety-samobójczynie spowodowały, że organizacja Boko Haram wykorzystuje w ponad $50 \%$ kobiety $(3 / 4 \mathrm{Z}$ nich to niepełnoletnie dziewczęta) do swoich misji (Davies, 2017, s. 109). Oprócz tej organizacji najaktywniejszą grupę zamachowczyń stanowią czeczeńskie terrorystki. Liczbę samobójczych ataków dokonanych przez czeczeńskie kobiety w 2008 roku szacowano na 42\% (Speckhard, Akhmedowa, 2005, s. 100), w 2017 na około 28-31\% (Davies 2017, s. 56).

Należy zaznaczyć, że włączanie kobiet w przygotowanie i przeprowadzenie zamachów samobójczych wynika z motywów taktycznych grup terrorystycznych. Efektywność terrorystek wiąże się z postrzeganiem natury kobiecej, kobiety z racji swojej płci są operacyjnie skuteczniejsze od mężczyzn (Alakoc, 2018). W żadnym jednak wypadku nie wpływa to na ich równouprawnienie w społeczności, w której funkcjonują. Wyjątkowość ich wyboru wpisuje się w kontekst historyczny, czasy szczególne, w których kobieta wykracza poza swoje tradycyjne role, by dodać otuchy, wzmocnić narrację, ukazać wyjątkowość działań. Kobieta staje się wciągnięta przez wir historii, przekracza swoje powołanie, by móc do niego powrócić w czasach normalnych. Wiąże się to z utrwaloną pozycją kobiet w czasie konfliktów zbrojnych, jako pozbawionych agencji (mocy sprawczej) a przymuszonych przez przeznaczenie, kosmiczne siły itd. oraz mających przyzwolenie mężczyzn (De Pauw, 1998).

Spiskowy charakter grup terrorystycznych uniemożliwia pozyskanie wiarygodnych informacji dotyczących znaczenia różnic biologicznych i kulturowych. Natomiast narracja terrorystek o sobie samych może być świadomie zafałszowana lub wynikająca 
z potrzeby racjonalizacji. Warto pamiętać, że miejsce kobiety w terroryzmie i w walce o sprawę należy postrzegać jako jej rolę w czasie wojny/konfliktu. Stąd społeczności tradycyjne w tej wyjątkowej sytuacji są w stanie zaakceptować jej udział na równi z mężczyznami. Nie znaczy to, że po osiągnięciu zamierzonych celów czy likwidacji grupy kobieta zachowa ten sam status. Raczej zakończenie „stanu wyjątkowego” wtłoczy ją w stereotypowe role żony, matki i córki. Różnice między płciami w czasach wojny i pokoju w oczach opinii publicznej różnią się tylko retoryką. Dlatego tak trudne jest oddzielenie relacji między płciami od pojmowania wojny, pokoju, przemocy i bezpieczeństwa. Dodatkowym wyzwaniem dla badacza jest określenie czyje doświadczenie konfliktu/ przemocy/walki zbrojnej jest uprzywilejowane (Pettman, 1996, s. 85).

Specyfika wielorakich ról i zadań $\mathrm{w}$ organizacji uniemożliwia stworzenie uniwersalnego portretu, dającego się zweryfikować w każdym ugrupowaniu, niezależnie od nurtu, z jakim jest powiązany. Szukając odpowiedzi na pytanie o źródła terroryzmu w ludzkiej naturze, marginalizuje się sposób, w jaki organizacje terrorystyczne rekrutują i motywują kandydatów/kandydatki. A jeśli terroryzm to droga kariery zawodowej? Czy te same czynniki rozwoju/gratyfikacji będą charakterystyczne dla kobiet i mężczyzn? Jednak, aby na te pytania odpowiedzieć, należałoby przeprowadzić ilościowo-jakościowe badania wśród aktywnych i byłych członków organizacji terrorystycznych. Niemniej wieloletni proces szkoleniowo-indoktrynacyjny może wypaczać interpretację impulsu, który popchnął w stronę przemocy. Usprawiedliwianie wyborów, racjonalizacja czy nadawanie sensu w imię wyższego dobra może zafałszować obraz (Taylor, Quayle, 1994).

Często przecenia się rolę więzi emocjonalnych, zapominając o modelu racjonalnego wyboru lub wymuszonego członkostwa. Organizacja terrorystyczna może być też szansą na przetrwanie, edukację i zdobycie pewnych umiejętności. Grupy zaliczane do prawicowych, w tym religijne, promują nierówne traktowanie płci i patriarchalny system relacji oraz stereotypowy rozdział tego, co męskie, od tego, co kobiece. Niezmiernie interesującym byłoby zbadanie motywów kobiet, które angażują się na rzecz właśnie tych organizacji oraz motywów samej organizacji w rekrutacji kobiecych członków (ucisk czy strategia?). Normy dotyczące płci wykorzystywane są też do rekrutacji mężczyzn, np. promowanie nagród w postaci zaślubin dla bojowników, dostępu do nieograniczonej liczby niewolnic seksualnych oraz obietnica w życiu pozaziemskim rozkoszy cielesnych itd.

\section{Gdzie są kobiety w badaniach nad terroryzmem?}

Feminizm przeżywa pewien impas związany z przeformułowaniem stawianych sobie celów działania, oceną sytuacji oraz potrzeb kobiet we współczesnym świecie. Wyrazem tego są nowe kierunki badań feministycznych oraz poszukiwanie perspektyw feministycznych w obszarach dotąd zmonopolizowanych (i zmaskulinizowanych) przez tradycyjne podejścia. Wybór tematyki bezpieczeństwa, a zwłaszcza zagadnień dotyczących przemocy politycznej jako przykładu pogłębionej analizy ze strony koncepcji feministycznych, podyktowany jest znaczeniem tej sfery w klasycznym ujęciu nauk społecznych. Studia nad bezpieczeństwem i zmiany zachodzące w tej dziedzinie są szczególnie istotnym zagadnieniem $\mathrm{w}$ obliczu nowych uwarunkowań międzynarodowych i wewnętrznych wpływających na przestępczość zorganizowaną, do której niewątpliwie za- 
licza się terroryzm. Stwarza to nowe wyzwania i potrzebę przedefiniowania koncepcji tradycyjnego uprawiania nauki i definiowania bezpieczeństwa. W tym kontekście nie da się pominąć partykularnych potrzeb kobiet w odniesieniu do bezpieczeństwa, ich roli w kształtowaniu bezpieczeństwa, a także eskalacji zagrożeń dla bezpieczeństwa z udziałem kobiet. Zagrożenia powinny być rozpatrywane w perspektywie, z której się wyłaniają, a płeć kulturowa jest ich częścią składową. Przykładem poszukiwania rozwiązań, które nie dyskryminowałyby kobiet, umożliwiając im pełne uczestnictwo i wpływanie na bezpieczeństwo, jest chociażby realizacja Agendy ONZ Kobiety Pokój Bezpieczeństwo (The Women, Peace and Security Agenda, WPS). O tym, że zmiany zachodzą, świadczy przyjmowanie przez kolejne państwa krajowych planów działania (National Action Plan's, NAP's) na rzecz realizacji Agendy WPS zgodnie z rezolucją RB ONZ nr 1325 (stan na grudzień 2019 r. - 83 państw posiada NAP).

W naukach społecznych uniwersalnym podmiotem zainteresowań badawczych była jednostka utożsamiana $\mathrm{z}$ mężczyzną. Stanowił on dominujący model działania, jego zachowania $\mathrm{w}$ relacji z innymi mężczyznami były ekstrapolowane przez analogię dla tłumaczenia zachowań związanych z przemocą polityczną czy z państwem. Mity towarzyszące pozycji kobiet w kontekście przemocy politycznej - ofiary, uchodźczyni, matki bolejącej, rozjemczyni - wzmacniają bagatelizowanie ich roli sprawczej również współcześnie. Wyraźny kontrast w postrzeganiu mężczyzn i kobiet w terroryzmie przekłada się również na wizje działań zapobiegawczych. Akcent na ukonstytuowane kulturowo role matki, opiekunki ogniska domowego, powierniczki, nośnika tradycji i zwyczajów utrwala pozycję kobiety w sferze prywatnej kojarzonej z kulturą. Więź matka-dziecko i generalnie opiekuńczość przypisywana kobietom zostaje wyszczególniona w relacjach społecznych, jako czynnik uzdrawiający oraz antyprzemocowy, a nie generujący zagrożenia. Aktywny i różnorodny udział kobiet w przemocy politycznej był zniekształcany lub marginalizowany. Czynnik płci w dalszym ciągu jest szczególnie widoczny w dyskursie o militaryzmie i jemu pokrewnych zjawiskach. Historia przemocy politycznej, tak samo jak historia wojen, wymaga świadectw istnienia i działania kobiet. Dlatego studia nad terroryzmem są jednym z tych obszarów, które winny być eksplorowane z wykorzystaniem podejścia feministycznego. Uwzględnianie doświadczenia kobiet nie oznacza tworzenia alternatywnej nauki, rozszerza horyzont poznania, uzupełnia go o kobiecą perspektywę. Marginalizowanie sprawczości kobiet i spychanie ich na pozycje ofiary niekoniecznie oznacza, że one same tak siebie postrzegają. Okradanie kobiet z mocy racjonalnego aktora, w ciągłym kontraście do mężczyzny - wojownika - lidera - zwycięzcy, jest fałszowaniem rzeczywistości, fatamorganą, w którą można wierzyć, a niekoniecznie budować na niej teorię poznania. Dlatego wyzwaniem dla badacza zjawiska brutalnego ekstremizmu jest potrzeba wykazania, że kobiece studia nad bezpieczeństwem, a w tym nad terroryzmem i radykalizacją, spełniają kryteria uniwersalności.

Terroryzm z udziałem kobiet nie jest zjawiskiem nowym, występował na długo przed zamachami z 11 września 2001 r. Dlatego powinien być badany tak, jak inne formy przemocy politycznej (rewolucje, pucze, wojny domowe) przez pryzmat jego źródeł strukturalnych, kulturowych, politycznych, ekonomicznych i religijnych. Brak wypracowania wspólnej definicji terroryzmu zarówno przez środowisko eksperckie, jak i decydentów politycznych nie jest przeszkodą w analizowaniu oraz zwalczaniu tego zjawiska. Niehomogeniczność terroryzmu, czyni go wyjątkowym przedmiotem badania, utrudnia jednak wykazanie pewnych 
prawidłowości, szczególnie w typowaniu potencjalnych ataków. Różnice między kobietami i mężczyznami w przemocy politycznej oraz w dywersyfikacji ról i zadań występują jak w każdej przestrzeni publicznej oraz prywatnej. Gender jako wytwór kultury ma tu ogromne znaczenie, przekraczanie barier tego, co kobiece i męskie może mieć wymiar strategiczny dla funkcjonowania/przetrwania organizacji terrorystycznej, a nie stricte emancypacyjny. Do tego dochodzi manipulacja cielesnością i seksualnością, jak i stereotypy oraz cechy przypisywane kobietom, co obniża świadomość potencjału zagrożenia.

Terroryzm z udziałem kobiet jest zagrożeniem realnym. Kobiety były aktywne na przestrzeni wieku XX przede wszystkim w organizacjach zaliczanych do nurtu narodowo-etnicznego i lewicowego. W obecnym stuleciu niepokojąco wzrasta ich znaczenie w terroryzmie dżihadystycznym, który generuje największą liczbę ofiar. Konkludując, można uznać, że najbardziej zagrożone radykalizacją w kierunku terroryzmu dżihadystycznego są osoby odczuwające, że wspólnota, z którą się utożsamiają, jest dyskryminowana. Kluczowe znaczenie ma tożsamość społeczna danej jednostki, której analiza może pozwolić przewidzieć z większą dozą prawdopodobieństwa jej zachowanie w przyszłości. Kolejnymi istotnymi kwestiami są seksualność, „pułapki czystości” i niedostosowanie haseł feministycznych świata zachodniego do potrzeb, wartości oraz oczekiwań młodych dziewcząt. Przełomem w aktywizacji kobiet były szerokie działania Państwa Islamskiego w latach 2014-2018. Wraz z erozją tej organizacji na terenie Iraku i Syrii zindoktrynowane i przeszkolone militarnie w niektórych przypadkach kobiety stanowić mogą realne, rozproszone globalnie zagrożenie. Często powracają do kraju pochodzenia razem ze zindoktrynowanym potomstwem.

Doświadczenie płci kulturowej i jej konstrukcja oraz mechanizmy w ugrupowaniach terrorystycznych i poza nimi poszerzają wiedzę o współczesności. Zjawisko radykalizacji kobiet do terroryzmu, szczególnie w organizacjach silnie mizoginicznych, pielęgnujących rozdział płci, ukazuje pewien mechanizm manipulacji tym, co męskie, a tym, co kobiece na poziomie rekrutacji i interpretacji. Doświadczenie tych kobiet jest analizowane z perspektywy męskiego przyzwolenia i pewnej tymczasowości. Pytaniem otwartym pozostaje, czy dzięki płciowym soczewkom w badaniach nad terroryzmem i radykalizacją systemy bezpieczeństwa wyglądałyby inaczej?

\section{Bibliografia}

Alakoc B. S. (2018), Femme Fatale: The Lethality of Female Suicide Bombers, „Studies in Conflict \& Terrorism", online: 10.09.2018, https://www.tandfonline.com/doi/abs/10.1080/1057610X. 2018.1505685, 02.12.2019.

Alexander A. (2016), Cruel Intentions: Female Jihadist in America, Washington DC, November 2016, https://extremism.gwu.edu/sites/g/files/zaxdzs2191/f/downloads/Female\%20Jihadists\%20 in\%20America.pdf, 02.01.2019.

Alison M. H. (2009), Women and Political Violence: Female Combatants in Ethno-National Conflict, Routledge, London-New York.

Anderson B. (2006), Imagined Communities, Reflection of the Origins and Spread of Nationalism, 2. Ed., Verso, London-New York.

Bakker E. (2006), Jihadi Terrorists in Europe, Their Characteristics and the Circumstances in Which They Joined the Jihad: An Exploratory Study, Clingendael Institute, The Hague 2006, https:// www.clingendael.org/sites/default/files/pdfs/20061200_cscp_csp_bakker.pdf, 15.07.2019. 
Bjørgo T. (red.) (2005), Root Causes of Terrorism: Myths, Reality and Ways Forward, Routledge, New York-London.

Bloom M. (2011), Bombshell: the many Faces of Women Terrorism, Hurst, London.

CPOST-SAD (2018), Chicago Project on Security and Terrorism, Suicide Attack Database http://cpostdata.uchicago.edu/search_new.php, 06.11.2018.

Cook J. (2019), A Woman's Place: US Counterterrorism since 9/11, Hurst \& Co Publishers, London.

Cunningham K. J. (2003), Cross-Regional Trends in Female Terrorism, „Studies in Conflict \& Terrorism", vol. 26, Issue 3.

Davies J. (2017), Women in Modern Terrorism, Rowman \& Littelfield Publishers, Lanham.

De Pauw L. G. (1998), Battle Cries and Lullabies. Women in War from Prehistory to the Present, University of Oklahoma Press, Norman.

Eckert R. (2009), Stufen der Radikalisierung und Exit-Optionen, „Policy: Politische Akademie”, nr 34, http://library.fes.de/pdf-files/akademie/berlin/06936.pdf, 2.12.2019.

Gasztold A. (2019), Udziat kobiet w organizacjach terrorystycznych. Hiperkobieta - hiperterrorystka, „Kwartalnik Naukowy OAP UW „e-Politikon” 2019, nr 30.

Groen J., Kranenberg A. (2010), Women Warriors for Allah. An Islamic Network in the Netherlands, trans. R. Naborn, University of Pennsylvania Press, Philadelphia-Oxford.

Herath T. (2012), Women in Terrorism: Case of the LTTE, Sage Publication, London.

Eltahawy M. (2016), Bunt. O potrzebie rewolucji seksualnej na Bliskim Wschodzie, tłum. M. Juszkiewicz, Prószyński i S-ka, Warszawa.

ICCT (2016), The Foreign Fighters Phenomenon in the European Union. Profiles, Threats \& Policies, ICCT (International Center for Counter-Terrorism), The Hague, April 2016, https://icct. nl/wp-content/uploads/2016/03/ICCT-Report_Foreign-Fighters-Phenomenon-in-the-EU_1April-2016_including-AnnexesLinks.pdf, 3.10.2019.

Jinan (2015), Esclave de Daech, avec Oberlé, T. Fayard, Paris.

Leede de S., Haupfleich R., Korolkova K., Natter M. (2017), Radicalisation and Violent Extremism - Focus on Women. How Women Become Radicalised and How to Empower Them to Prevent Radicalisation, „Study Committee on Women's Right \& Gender Equality”, 21.12.2017, http:// www.europarl.europa.eu/RegData/etudes/STUD/2017/596838/IPOL_STU(2017)596838_ EN.pdf, 8.11.2019.

Lützinger S. (2010), Die Sicht der Anderen. Eine qualitative Studie zu Biographien von Extremisten und Terroristen, Luchterhand, Köln.

Khalaf F., Hoffman A. C. (2016), The Girl Who Escaped ISIS: This is My Story, Square Peg, London.

Klausen J (2014), They're Coming: Measuring the Threat from Returning Jihadist, 1.10.2014, „Foreign Affairs".

Millett K., Theory of Sexual Politics, w: Feminist Theory: A Philosophical Anthology, red. A. E. Cudd, R. O. Andreasen, Blackwell Publishing, Malden MA.

Ness C. D. (2005), In the Name of the Cause: Women's Work in Secular and Religious Terrorism, „Studies in Conflict \& Terrorism", vol. 28, Issue 5.

Pettman J. J. (1966), Worlding Women: A Feminist International Politics, Routledge, London-New York.

Pearson E. (2016), The Case of Roshonara Choudhry: Implications for Theory on Online Radicalization, ISIS Women and the Gendered Jihad, „Policy and Internet”, March, vol. 8, Issue 1.

Shiffman Ch. (2012), Jane's jihad. Form Abuse to Chat Room: the Martyr is Made, 7.12.2012.

„Special Reports Reuters”, http://graphics.thomsonreuters.com/12/12/JihadJaneAll.pdf, 21.01.2019.

Schmid A. P. (2013), Radicalisation, De-Radicalisation, Counter-Radicalisation: a Conceptual Discussion and Literature Review, „ICCT Research Paper”, March, https://www.icct.nl/download/file/ICCT-Schmid-Radicalisation-De-Radicalisation-Counter-RadicalisationMarch-2013.pdf, 4.12.2019. 
Speckhard A., Akhmedowa K. (2008), Black Widows and Beyond. Understanding the Motivation and Life Trajectories of Chechen Female Terrorist, w: C. D. Ness, Female Terrorism and Militancy: Agency, Utility, and Organization, Routledge, London-New York.

Tajfel H., Turner J. C. (1979), An Integrative Theory of Intergroup Conflict, w: The Social Psychology of Intergroup Relations, red. S. Worchel, W. G. Austin, Brooks/Cole Pub., Monterey.

Taylor M., Quayle E. (1994), Terrorist Lives, Potomac Books, London.

Tickner A. J. (1995), Re-visioning Security, w: International Relations Theory Today, red. K. Booth, S. Smith, Polity Press, Cambridge.

Quazi F. (2011), The Mujahidaat, Tracing the Early Female Warriors of Islam, w: Women, Gender and Terrorism, red. L. Sjoberg, C. E. Gentry, The University of Georgia Press, London.

Vergani M. (2018), The Three Ps of Radicalization: Push, Pull and Personal. A Systematic Scoping Review of the Scientific Evidence about Radicalization Into Violent Extremism, „Studies in Conflict and Terrorism", online 10.09.2018, https://www.tandfonline.com/doi/full/10.1080/ 1057610X.2018.1505686, 5.11.2019.

Victor B. (2003), Army of Roses: Inside the world of Palestinian women suicide bombers, Rodale, Emmaus.

Wejkszner A. (2018), Samotne wilki Kalifatu? Państwo Islamskie indywidualny terroryzm dżihadystyczny w Europie Zachodniej, Difin, Warszawa.

Zięba A., Szlacher D. (2015), Countering Radicalisation of Muslim Community Opinions on the EU Level, „International Studies. Interdisciplinary Political and Cultural Journal”, vol. 17, no. 1.

Zięba A. (2015), Problem udziału kobiet $w$ organizacjach terrorystycznych, w: Terroryzm wczoraj i dziś: wybrane problemy, red. P. de la Fuente, W. Gizicki, C. Taracha, Instytut Sądecko-Lubelski, KUL, Lublin.

\section{Studies on female radicalisation to jihadi terrorism}

\section{Summaty}

The aim of the article is to analyze the women's participation in jihadist movements through feminist perspectives. The hypothesis of this paper is the assumption that the factors determining and initiating the fascination with leads to political violence may be different among women and young girls than among men. The cultural and social determinants and perceived female roles in particular communities are of particular importance. The specifics of the socialization of women to political violence are not in contrast to the radicalization of men but should be considered as a complement to studies on terrorism. There are indications of radicalization of attitudes and behaviors, including individual factors pushing and sustaining involvement in terrorism (push and pull factors). The following methods have been applied in the article: theoretical research methods (classification and systematization, verification), general-purpose methods (analysis, synthesis, induction, deduction) and other research methods typical for social sciences: statistical, comparative, descriptive, analysis of sources, analysis and criticism of the literature on the subject. The conclusion was that manipulation of masculinity and femininity is used not only by terrorist groups in recruitment processes, but also in the analysis of this phenomenon itself. Gender relations also affect accepted interpretive solutions of phenomena in which women participate, and above all, their marginalization in violence studies.

Key words: female terrorism, feminism, jihadi terrorism, radicalisation, women 